\title{
Innovative Curriculum that forms Entrepreneur Engineers
}

\author{
Jorge Adrian Salas Ruiz, Doctor en Ciencias en Ingeniería \\ Cesar Vallejo University, Perú jsalas@ucv.edu.pe
}

\begin{abstract}
Cesar Vallejo University has updated the curricula of its degree-courses, aligning them with the current needs of society, and reinventing itself as an "innovating university that forms entrepreneurs".

The Strategic Plan 2017-2021 has as a general objective the professional training of creative and innovative citizens with ethical principles, who research and lead ventures that contribute to the development of society.

The curriculum considered the conceptualization of the educational model aligned with the strategic axis of the university, the Peruvian technical standards NTP-ISO 10004-2014 for Customer satisfaction, Guidelines for monitoring and measurement, NTP-833.924-2009 Guide for Curricular Design of Educational Programs, and ISO 9001-2015 Quality Management Systems.
\end{abstract}

This curriculum establishes the profile of engineers, their philosophical and pedagogical foundations, the institutional purposes that guide teaching, research, university social responsibility, and internationalization; prioritizing formative research, training by competencies and the humanist approach in the training of engineers.

Keywords- Innovative Curriculum; Entrepreneurial Engineers; Quality Management Systems.

\section{INTRODUCTION}

The trends of higher education in this century require universities to take on new challenges and make the best decisions in the training of professionals that a society as competitive as the one we live in today demands.

Within the context of continuous improvement, the revision of the curricula is an activity that contributes to raising the levels of quality in the processes, services and results of university education. Given that situation, César Vallejo University, an innovative, scientific, and technological institution with a broad sense of social responsibility, ordered the updating of the curricula of all the professional degreecourses offered by its twelve institutional campuses.

Digital Object Identifier (DOI):

http://dx.doi.org/10.18687/LACCEI2019.1.1.46

ISBN: 978-0-9993443-6-1 ISSN: 2414-6390
The Faculty of Engineering is composed of 8 engineering degree-courses: Environmental, Agribusiness, Civil, Industrial, Business, Mining, Systems and Mechanicalelectrical. At the end of 2017, the Faculty of Engineering had a total of 30,401 students, 779 university teachers and 2,631 graduates, developing their teaching/learning activities in its 40 professional degree-courses decentralized across the country, a fact that forced a gradual design and implementation of the new curriculum to include aspects such as: theoretical foundation, global participation, flexibility and methodology; taking into account in its design-control such stages as: review, verification and validation, as well as the management of changes in curricular design and the designation of responsibilities, as stipulated in the Peruvian Technical Norm NTP 833.924: 2009.

\section{CONTEXT}

The new Strategic Plan 2017-2021 of César Vallejo University, has as its main objective the professional training of creative, innovative citizens with ethical principles, who research and lead ventures contributing to the development of society [1]; a guiding document that guided César Vallejo University in the process of updating the curricula of its degree-courses, aligning them with the current demands of society, rebranding itself as an "innovative university that trains entrepreneurs".

In accordance with the aforementioned institutional policy, the Faculty of Engineering proceeded to review the curriculum through a continuous process, based on the participatory work of students, graduates, university-teachers, university authorities and representatives of interest-groups, in order to contribute to perfecting the process of formation and to elaborate a proposal that guarantees quality education with humanist sense and social commitment.

César Vallejo University, in line with its educational model, intends to integrate technical and academic aspects of people management, in order to enhance the human nature of its graduates.

Based on the perception that university students have access to this type of initiative, the results lead us to reflect on the role of universities in creating potential entrepreneurs. Thus, there are still several areas of opportunity in which we must work to strengthen entrepreneurial activity in universities [2]

This curricular proposal emphasizes the formation of people capable of permanently searching for the truths that

$17^{\text {th }}$ LACCEI International Multi-Conference for Engineering, Education, and Technology: "Industry, Innovation, And Infrastructure for Sustainable Cities and Communities”, 24-26 July 2019, Jamaica. 
correspond to formal reality and to take on, in their daily life, behaviors that are based on ethical, civic, ecological and aesthetic values, which allow them to actively participate as productive agents.

Entrepreneurship is, today, a strategy for the economic and social development of countries and regions as it takes advantage of and promotes the initiative of individuals or small groups with a great desire for economic independence and a sense of achievement, to generate a virtuous circle of prosperity, innovation, growth and development [3].

Entrepreneurial activity is a critical success-factor for the progress of the region. In this context, the training of entrepreneurial professionals contributes to the economic development and strengthening of the social capital of a country, because the entrepreneurial students develop attitudes, skills and behaviors that will allow them to progress in their professional degree-courses and, at the same time, stimulate the local socio-productive framework. The university is a factor [4]

Entrepreneurship in Peru has been considered one of the main reasons for economic growth and development of the country, because the creation of new companies and job opportunities, results in the increase of employment. The different economic progress and setbacks mentioned above have placed Peru as the fifth-biggest country in entrepreneurial activity in Latin America... however, there are gaps not yet overcome by the country, such as the lack of financing, quality of ventures, technical knowledge at the time of implementing ventures...; PRODEM, the Regional of Ecosystems and Entrepreneurship Monitoring Program for Latin America, established that since 2014 it was appropriate to consider Peru as one of the economies that would become a generator of quality ventures with impact on the economic development [5]

\section{METHODS}

\section{A. Planning}

The curricular change for the Schools of Engineering was developed taking into account the Guidelines on Entrepreneurship established in the Strategic Plan 2017 2021, from which the Educational Model of the innovative curriculum to train entrepreneurs was formulated and conceptualized, that defined the academic guidelines to be taken into account, basic elements that allowed the design and implementation of the curriculum in its three sub-steps: (a) Awareness, through the counseling and training of the Directors through the specialized Diploma course: "Entrepreneurship and Innovation in the University Institution"; exchange of successful experiences with Los Andes University of Colombia; (b) Design, which was developed taking into account the Peruvian Technical Standard (NTP) 833.924: 2009, which considers the input elements, process and output elements, where the educational objectives, graduate competencies, curriculum, summaries, conceptual framework and structure of the enterprise were defined, and (c) Implementation, which considers training, infrastructure, support networks and equipment.

This process will allow us to have results in venturetraining and development, measured through the satisfaction of graduates and interest-groups with the NTP-ISO 10004: 2014 which will provide feedback for curriculum update and evaluation of the Strategic Plan. As can be seen in "Fig. 1"

The design and implementation of the curriculum considered the conceptualization of the educational model aligned with the strategic axis of the university, the Peruvian technical standards NTP-ISO 10004-2014 for Customer satisfaction, Guidelines for monitoring and measurement, the NTP-833.924-2009 Guide for Curricular Design of

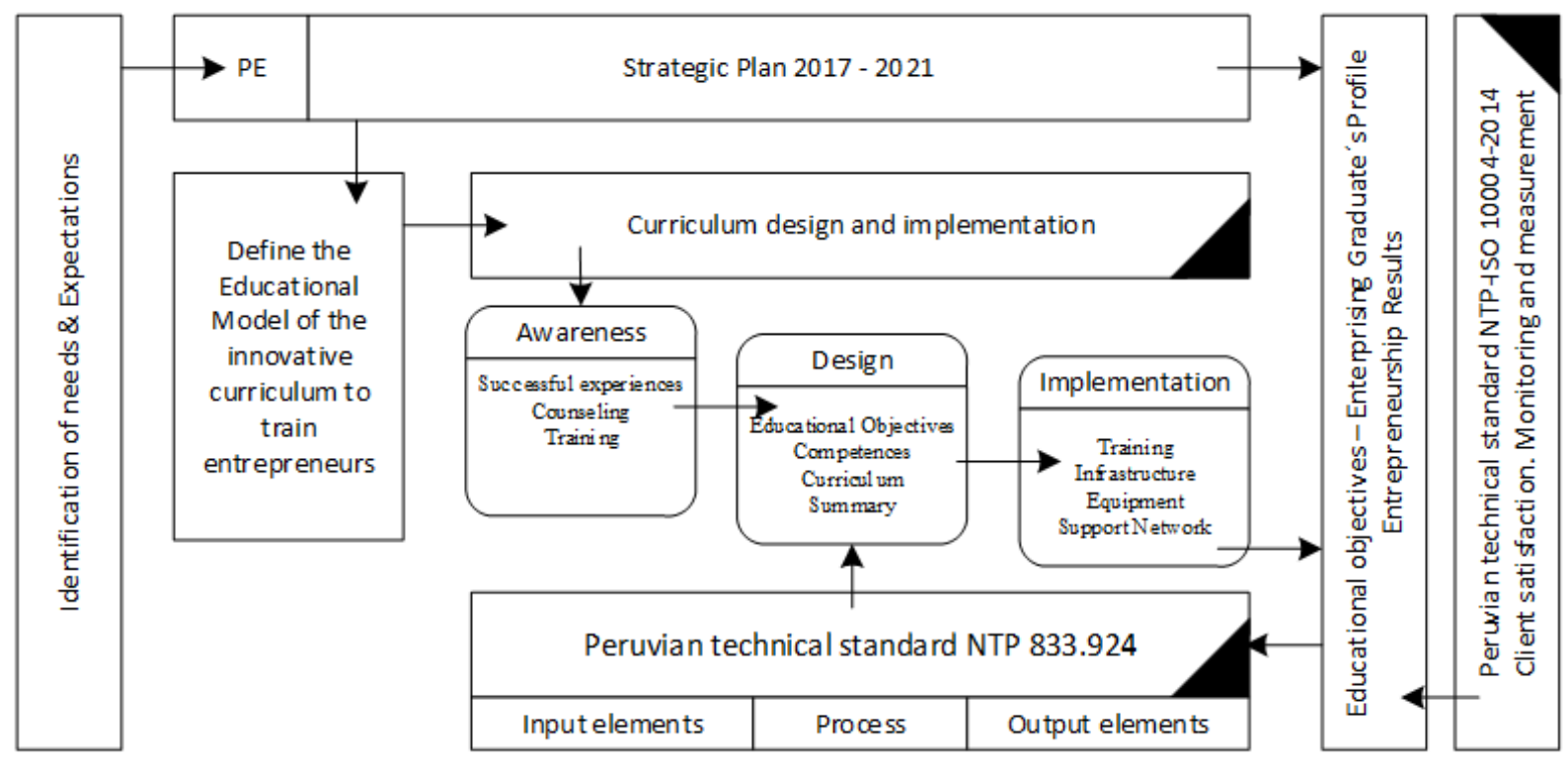

Fig. 1 Planning activities to implement the new curriculum

$17^{\text {th }}$ LACCEI International Multi-Conference for Engineering, Education, and Technology: "Industry, Innovation, And Infrastructure for Sustainable Cities and Communities", 24-26 July 2019, Jamaica. 
Educational Programs, and the ISO 9001-2015 Quality Management Systems, which regulate the main operating and support processes.

\section{B. Curricular design:}

The following stages were considered in the curricular design according to NTP 833.924-2009[6]:

1. Identification of needs: This is the initial stage of the process, to determine the need to design new curricular-plans, or update current ones.

2. Curricular design planning: The educational organization must plan and manage the curricular design. Planning should include the stages and management of design and those responsible for it.

3. Determination of the input elements: In this stage, based on the identification of needs, the customer's requirements are established, which become inputelements of the design. The corresponding legal requirements must also be considered.

4. Curricular design development: This is the stage at which, through the participation of the different levels of the educational organization, the curricular design is developed.

5. Curricular design application: Once the stage of preparation and approval of the Curricular Design or its update is completed, it is applied, after training those personnel directly involved in its implementation.

\section{Monitoring and Measurement}

According to the NTP-ISO 10004: 2014 [7], one of the key elements of organizational success is client satisfaction with the organization and its products. Therefore, it is necessary to track and measure customer satisfaction.

The information obtained from monitoring and measuring customer satisfaction can help identify opportunities for improvement of the organization's strategies, products, processes and features that are valuable to customers, and serve the objectives of the organization. Such improvements can strengthen the costumer's trust and result in commercial gain or other benefits.

The process of measuring our clients' satisfaction is carried out during the training process in the academic service provided by the University, and in the follow-up system for graduates, which lasts three years, so we can evaluate their performance and achievement regarding the educational objectives, elements that became inputs for the design of the proposed curriculum.

\section{RESULTS}

\section{A. Internal and External Evaluation of the Curriculum.}

Taking into account the internal and external evaluation criteria of the curricular evaluation system and the internal and external input elements, the variables were established though a coherence matrix (internal and external input elements) to take into account for measurement in Internal and External Evaluation:

The revision, verification and validation of each of the input elements, taking into account the context, led to the proposal of the new design and implementation of the curriculum for the training of Entrepreneurial Engineers.

A.1. Internal Evaluation

Internal Evaluation Criteria (CEI):

CEI1. Analysis of the consistency or coherence between the curricular objectives in relation to the correspondence and proportion between them, as well as the areas and contents specified.

CEI2. Analysis of the validity of the competencies for confirmation or correction, based on the information obtained from the analysis of the student demographics, scientific developments and social changes.

CEI3. Analysis of the curriculum viability considering the existing human and material resources.

CEI 4. Analysis of the sequence and dependence between resources, as well as their suitability.

CEI 5. Analysis of content adaptation and curricular activities to the principles that control the educational model.

CEI 6. Analysis of the operative functioning of the academic-administrative institutional and inter-institutional aspects.

CEI7. Research into teaching activity and its relationship with student performance.

CEI 8. Research into factors related to academic performance of students, especially causes and rates of failure, drop-out, academic-achievement levels, etc., as well as teaching-learning strategies, evaluation, motivation factors and personal factors associated with academic performance.

Internal Input Elements according to NTP 833.924-2009 (EEI):

EEI1. Strategic project of the educational institution

EEI2. Strategic degree-course plan

EEI3. Educational model

EEI4. Current curricular plan

EEI5. Educational objectives

EEI6. Results of reviews, verifications and validations of current curricular design (indicators)

EEI7. Intake-student profile

EEI8. Graduating-student profile

EEI9. Teacher opinion report

EEI10. Student opinion report and analysis of satisfaction level

EEI11. Teacher competencies profile

$17^{\text {th }}$ LACCEI International Multi-Conference for Engineering, Education, and Technology: "Industry, Innovation, And Infrastructure for Sustainable Cities and Communities”, 24-26 July 2019, Jamaica. 
Table 1. Coherence matrix behe Internal Input Elements (EEI) and the internal evaluation criteria of the curriculum

\begin{tabular}{|c|c|c|c|c|c|c|c|c|c|c|c|}
\hline \multirow{2}{*}{ Evaluation criteria of the curriculum } & \multicolumn{11}{|c|}{ Internal Input Elements } \\
\hline & EEI1 & EEI2 & EEI3 & EEI4 & EEI5 & EEI6 & EEI7 & EEI8 & EEI9 & EEI10 & EEI11 \\
\hline $\begin{array}{l}\text { CEI1 Consistency or coherence between the curricular } \\
\text { objectives }\end{array}$ & & & $\mathrm{X}$ & & $\mathrm{X}$ & & $\mathrm{X}$ & $\mathrm{X}$ & & & \\
\hline CEI2. Validity of the competencies & & & & $\mathrm{X}$ & & $\mathrm{X}$ & $\mathrm{X}$ & $\mathrm{X}$ & & & \\
\hline CEI3. Curriculum viability & & & $\mathrm{X}$ & & & $\mathrm{X}$ & & & & & \\
\hline CEI4. Sequence and dependence between resources & $\mathrm{X}$ & $\mathrm{X}$ & & & & & & & & & \\
\hline CEI5. Content adaptation and curricular activities & & & $\mathrm{X}$ & & & & & & & & \\
\hline CEI6. Operative functioning & $\mathrm{X}$ & $\mathrm{X}$ & & & & & & & & & \\
\hline CEI7. Research into teaching activity & & & & & & & & & $\mathrm{X}$ & $\mathrm{X}$ & $\mathrm{X}$ \\
\hline CEI8. Academic performance & & & & & & $\mathrm{X}$ & & & $\mathrm{X}$ & $\mathrm{X}$ & \\
\hline
\end{tabular}

\section{External Evaluation}

CEE1 Continuous research of social needs to be addressed by the professional.

CEE2. Continuous research of the job market and the skills required for graduates, to change or expand the aspects developed in the stage of curricular organization and structuring.

CEE3. Research into the impact of work performance in the different areas specified in the professional profile, both in the short and long term, in the solution of stated problems.

CEE4. Research into professional functions developed in work performance, regarding the training offered in our degree-course compared to other institutions.

\section{External Input Elements, according to NTP 833.924-2009}

EEE1. Profile of the secondary-education graduate

EEE2. Profile of the non-university higher-education graduate

EEE3. Analysis of trends in university-based higher-education

EEE4. National strategic plan

EEE5. Local and regional development plan

EEE6. Diagnosis and prospective analysis of the occupational field

EEE7. Prospective career analysis

EEE8. Graduates' opinion

EEE9. Employers' opinion

EEE10. Professional-college's opinion

EEE11. Experts' opinion

EEE12. Situation of competitors

EEE13. Applicable legal regulations

\section{A. Training Model of enterprising engineers:}

The context in which the Engineering Study Program was developed is related to the trends in Engineering Training in Latin American universities, the new educational paradigms, quality accreditation, licensing and the incorporation of the new University Law.
These elements required an organization of the teachinglearning process and curricular models that were characterized by being interactive and collaborative, student-focused and enabling them to achieve lifelong learning that guarantees the training of engineers who will promote change and be responsible for the technological development of Peru.

The Faculty of Engineering took on this challenge of leading the process of transformation in society, as well as constantly creating knowledge to enable change in accordance with the social reality which it develops in, transforming itself and taking in the requirements of the new reality, which led it to propose a Training Model for Enterprising Engineers "Fig. 2" based on: (a) A competency-based curriculum, (b) Integrated student training, (c) Formative research, (d) Graduation-level research, (e) In-Service Learning, (f) Entrepreneurship, (g) Teacher-performance Assessment, (h) Graduate follow-up system, (i) Entrepreneurial Curriculum, (j) Progressive certification, (k) Social Responsibility and (1) Foreign Language.

This guarantees the training of Entrepreneurial Engineers with a solid scientific-technological formation, connected and supported in their training processes and the design of an open and flexible curriculum, in which significant learning predominates, with the aim of training modern, creative and caring professionals, not only knowledgeable in their specialty, but in the skills and abilities to take decisions, take on social responsibilities, elements that allow the developing of a competent engineer, able to interact and solve economic, environmental and scientific-technological development problems.

Given this context, the educational model for the training of engineers is aimed at training students as competent professionals and citizens through an education for innovation and entrepreneurship based on science, technology and research, with

Table 2. Coherence Matrix of External Input Elements (EEE) and external evaluation criteria of the curriculum (CEE).

\begin{tabular}{|c|c|c|c|c|c|c|c|c|c|c|c|c|c|}
\hline \multirow[b]{2}{*}{ External Evaluation Criteria } & \multicolumn{13}{|c|}{ External Input Elements } \\
\hline & EEE1 & EEE2 & EEE3 & EEE4 & EEE5 & EEE6 & EEE7 & EEE8 & EEE9 & EEE10 & EEE11 & EEE12 & EEE13 \\
\hline CEE1. Social needs & & & $\mathrm{X}$ & $\mathrm{X}$ & $\mathrm{X}$ & & & & & $\mathrm{X}$ & $\mathrm{X}$ & & \\
\hline CEE2. Job market & $\mathrm{x}$ & $\mathrm{X}$ & & & $\mathrm{x}$ & $\mathrm{X}$ & $\mathrm{x}$ & & & $\mathrm{x}$ & & $\mathrm{x}$ & \\
\hline CEE3. Impact of work performance & & & & & & & & $\mathrm{X}$ & $\mathrm{X}$ & $\mathrm{X}$ & $\mathrm{X}$ & & \\
\hline CEE4. Professional functions & & & & & & & $\mathrm{x}$ & $\mathrm{X}$ & $\mathrm{X}$ & $\mathrm{X}$ & $\mathrm{x}$ & & $\mathrm{x}$ \\
\hline
\end{tabular}

$17^{\text {th }}$ LACCEI International Multi-Conference for Engineering, Education, and Technology: "Industry, Innovation, And Infrastructure for Sustainable Cities and Communities", 24-26 July 2019, Jamaica. 


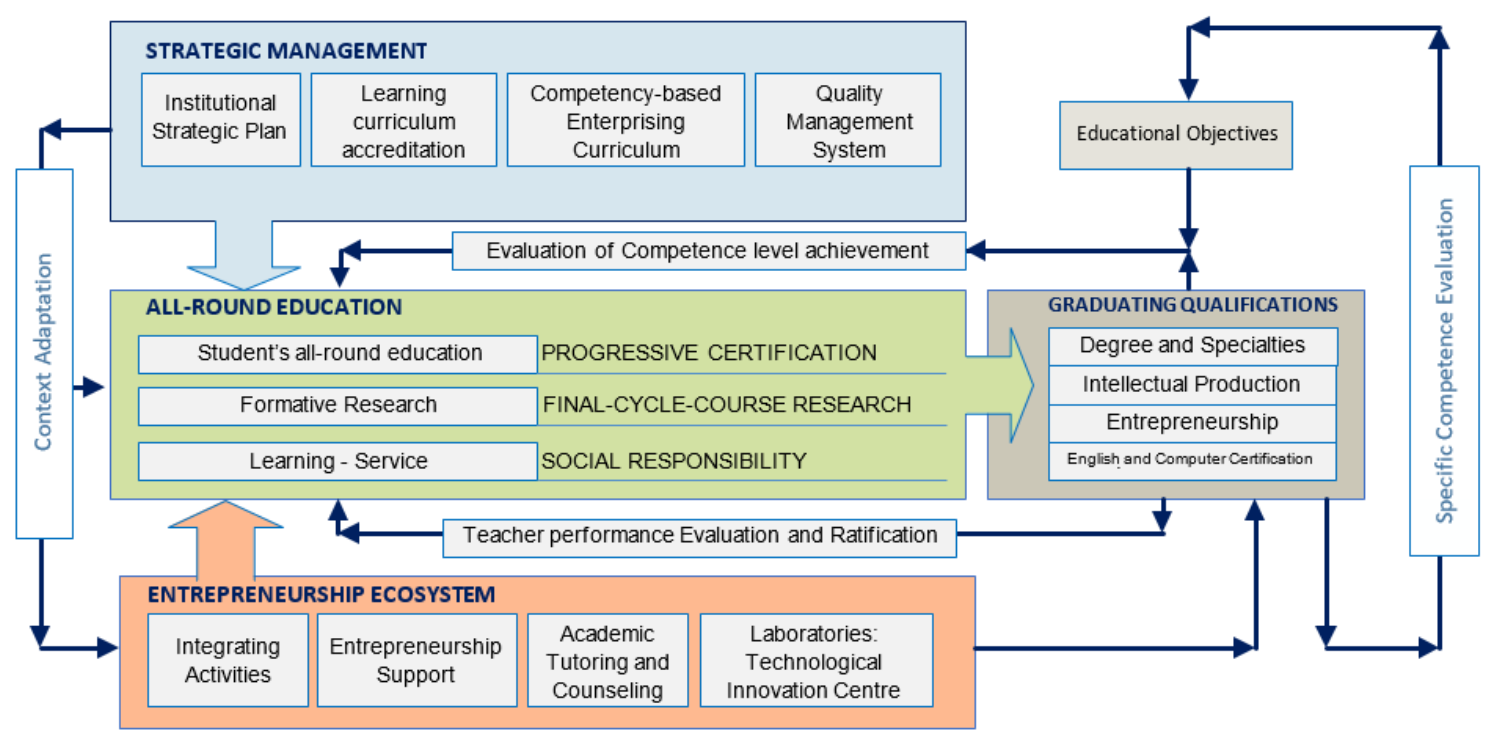

Fig. 2 Training Model for Enterprising Engineers

emphasis on their personal and integral training. In that sense, César Vallejo University is known as a university committed to the development of the country and capable of contributing to the solution of problems that today's society faces. This can be seen in its vision for 2021; César Vallejo University is known as an innovative university that trains entrepreneurial professionals.

\section{CONCLUSIONS AND RECOMMENDATIONS}

The curricular proposal establishes the profile of the Engineer, the philosophical and teaching foundations, the institutional purposes that guide teaching, research, university's social responsibility, and internationalization; prioritizing formative research, competence training and the humanist approach in the training of engineers.

This curriculum should always be considered in its contemporary dynamics, and be subject to permanent review, with ideas that will serve as the basis for revision, because that is and should be the strength that defines academic development in the university, creating suitable and flexible programs, but with the same academic rigor.

Our curricular teaching-learning proposal is based on the humanist, sociocultural and constructivist currents, the same ones that aim to get the student to learn how to learn, adapt easily to changes and solve problems from a professional perspective.

In this world, where information changes at an accelerated pace, knowledge quickly becomes outdated, so this proposal is aimed at stimulating meaningful and sustainable learning, which will allow students to be part of their society, having a dignified occupation, today and in the future.

This curriculum can be perfected to the extent that it is adapted to current requirements and needs. However, its implementation is a challenge, but at the same time a reality that will allow continual training of professionals that the country needs.

\section{REFERENCES}

[1] Universidad César Vallejo, «Plan Estratégico 2017 - 2021,» Fondo Editorial Vallejiano, Trujillo, 2017.

[2] Guerrero, Maribel; Urbano, David; Ramos, Antonio R., «Observatorio de Emprendimiento Universitario 2015 - 2016,» RedEmprendia, España, 2016.

[3] O. Alvarado Muñoz, «Universidad y emprendimiento, aportes para la formación de profesionales emprendedores,» Cuadernos de Administración - Universidad del Valle Vol 27 - No 45, pp. $61-74,2011$.

[4] S. R. Andrés María y V. Daniea, «Una década formando emprendedores en la Universidad Nacional del Litoral,» Revista Pymes, Innovación y Desarrollo, vol. 2, nº 2, pp. 3 -19, 1014.

[5] Montesinos Alarcón, Ormeño Bustios, Piña Manrique, «El Rol de las Incubadoras de Negocios Universitarias dentro del Ecosistema Emprendedor Peruano - TESIS,» Pontificia Universidad Católica del Perú, Lima, 2018.

[6] Norma Técnica Peruana NTP 833.924:2009, «Guía para el diseño curricular de programas educativos, dentro de un sistema de gestión de la calidad en una organización educativa.,» INACAL, Lima, 2009.

[7] Norma Técnica Peruana NTP-ISO 10004:2014, «Gestión de calidad. Satisfacción del cliente. Directrices para el seguimiento y medición.,» INDECOPI, Lima, 2014.

$17^{\text {th }}$ LACCEI International Multi-Conference for Engineering, Education, and Technology: "Industry, Innovation, And Infrastructure for Sustainable Cities and Communities", 24-26 July 2019, Jamaica. 